\title{
РЕАЛІЗАЦІЯ МІЖДИСЦИПЛІНАРНОЇ ІНТЕГРАЦІЇ ПРИ ВИВЧЕННІ ХІМІЧНИХ ДИСЦИПЛІН СТУДЕНТАМИ ФАРМАЦЕВТИЧНОГО ФАКУЛЬТЕТУ
}

\author{
М. М. Михалків, А. С. Демид, М. Б. Чубка, І. Б. Івануса \\ ДВНЗ “Тернопільський держсавний медичнийуніверситет імені І. Я. Горбачевського МОЗ Украйни”
}

\section{REALIZATION OF INTERDISCIPLINARY INTEGRATION AT THE STUDY OF CHEMICAL DISCIPLINES BY STUDENTS OF PHARMACEUTICAL FACULTY}

\author{
M. M. Mykhalkiv, A. Ye. Demyd, M. B. Chubka, I. B. Ivanusa \\ SHEI "Ternopil State Medical University by I. Ya. Horbachevsky of MPH of Ukraine”
}

\begin{abstract}
У статті описані міжпредметні зв'язки при вивченні хімічних дисциплін (неорганічної, органічної, аналітичної, біологічної, фізико-колоїдної, фармацевтичної, токсикологічної хімії) студентами фармацевтичного факультету Тернопільського державного медичного університету імені І. Я. Горбачевського.
\end{abstract}

The interdisciplinary communication at the study of chemical disciplines (inorganic, organic, analytical, biological, physical and colloid, pharmaceutical, toxicological chemistry) by students of pharmaceutical faculty of Ternopil State Medical University by I.Ya. Horbachevsky is described in the article.

Вступ. Доцільним і важливим у кредитномодульній системі навчального процесу є розвиток міждисциплінарної інтеграції, що дозволяє не тільки перевірити, але й систематизувати надбані протягом навчання знання.

Тому метою роботи є показати можливості міжпредметної інтеграції при вивченні студентами хімічних дисциплін упродовж усього навчання на фармацевтичному факультеті.

Основна частина. Стратегічною лінією підготовки випускників фармацевтичного напряму є комплексне вивчення спеціальних дисциплін. Необхідність комплексування викладання на спеціальних кафедpax обумовлена складанням підсумкового міждисциплінарного іспиту при державній атестації випускників. Це пов'язане з тим, що в майбутній професійній діяльності фахівцям-провізорам необхідно буде вирішувати питання, що зачіпають всі зазначені дисципліни спільно. Тому випускники повинні вміти синтезувати знання, отримані з усіх спеціальних дисциплін, для вирішення ситуаційних завдань, що виникають у процесі роботи. Для того щоб студенти могли адаптуватися до такої ситуації, їх необхідно готувати в процесі навчання [1].
Однією з форм реалізації міжпредметних зв'язків може бути досягнення високого рівня узагальнення, що особливо важливо для сприйняття цілісності, компактності набутих знань, вміння коректно вирішувати поставлені завдання та проблеми - це головна мета міждисциплінарної інтеграції. Цей процес потребує спеціальної організаційної роботи викладача 3 навчання студентів міжпредметного синтезу за допомогою багатосторонніх міжпредметних зв'язків навколо головних положень навчальної теми, основних ідей навчального предмета, науки [2-5].

Науковість, системність, мобільність та потенціал світосприйняття знань студентів значно залежать від вміння встановити міжпредметні зв'язки.

Самостійність студентів щодо виявлення та відтворення міжпредметних зв'язків формується в результаті цілеспрямованої діяльності викладача, яка забезпечує розвиток у студентів навичок з виявлення навчальної теми та ідеї всього предмета, розвиток вмінь для організації вивчення навчального матеріалу довкола стержневих понять теми та дисципліни в цілому на широкій міжпредметній основі, визнанні студентом важливості міждисциплінарного синтезу як у навчальній, так і в практичній роботі.

() М. М. Михалків, А. С. Демид, М. Б. Чубка, І. Б. Івануса 
Першою базовою дисципліною, яка вивчається студентами фармацевтичного факультету, є неорганічна хімія. Специфіка предмета “Загальна та неорганічна хімія" на фармацевтичному факультеті медичного (фармацевтичного) ВНЗ полягає в тому, що вона готує теоретичну базу для формування професійної компетенції в майбутньому на старших курсах.

Велику роль у цьому відіграє інтеграція, тобто реалізація комплексних міждисциплінарних (наскрізних) програм, що сприяє переходу методів з однієї галузі знання в іншу. Всі розділи загальної й неорганічної хімії $€$ необхідними при вивченні наступних хімічних, спеціальних і професійних дисциплін, що сприяє формуванню в студентів професійної компетенції [2-4].

Наприклад, знаючи основи хімічної кінетики, студент може обгрунтувати умови зберігання лікарських засобів та реактивів. Так, зберігати препарати гідроген пероксиду необхідно при пониженій температурі, у темному місці, тому що процес розкладання гідроген пероксиду є ендотермічною реакцією і на світлі процес прискорюється (кванти світла ініціюють утворення радикалів). Препарати, що містять ферум (II) сульфат, варто зберігати на світлі, тому що кванти світла гальмують процеси окиснення ферум (II) до ферум (III) [2].

Знання, які отримують студенти при вивченні курсу загальної та неорганічної хімії, поглиблюються при вивченні аналітичної хімії, фізичної та колоїдної хімії на другому курсі, фармацевтичної хімії на третьому та четвертому курсах. Органічна та аналітична хімії - базові дисципліни, на основі яких вивчаються біологічна і фармацевтична хімія. Токсикологічна хімія вивчається на 4 і 5 курсах фармацевтичного факультету - це дисципліна, яка узагальнює знання зі всіх хімічних дисциплін, отримані на попередніх курсах, а також включає знання з фармакології.

Окрім того, знання неорганічної хімії необхідні для вивчення нормальної й патологічної фізіології людини, біохімії, професійних медичних дисциплін. Вони забезпечують глибокий зв' язок хімічної та медичної (фармацевтичної) освіти, перенесення знань загальної хімії в рішення професійно-практичних завдань і покликані задовольнити освітньо-професійні потреби студентів, зацікавлених у вивченні, розширенні й поглибленні деяких важливих для фармацевтичної освіти питань загальної хімії [2].

Наведемо приклади реалізації принципів наступності та безперервності при вивченні деяких тем з неорганічної хімії при підготовці провізорів на фармацевтичному факультеті.

\section{Тема заняття: "Вчення про розчини"}

Однією із найбільш важливих і професійно спрямованих у структурі загальної хімії для медичних вузів $€$ тема "Вчення про розчини". Системоутворювальним поняттям даної теми є загальне фундаментальне поняття про розчини. Найбільш поширеними та вивченими є рідкі водні розчини. Вони мають важливе значення для життєдіяльності організму, оскільки процеси засвоєння їжі людиною пов' язані з переходом харчових речовин у розчин. Розчинами є важливі фізіологічні рідини - кров, лімфа тощо [6].

Не менш важливе значення мають розчини у фармацевтичній практиці. Вони є найбільшою групою серед лікарських форм. Як лікарська форма розчини мають ряд переваг: вони порівняно з іншими лікарськими формами швидше всмоктуються організмом людини, відповідно швидше досягається лікувальний ефект; їх технологія відрізняється простотою. Грунтовний підхід щодо вивчення даної теми дозволить в подальшому поглибити отримані знання при вивченні аналітичної, фармацевтичної хімії, аптечної та заводської технології ліків.

У даній темі також необхідно наголосити й про розчинність газів та залежність розчинності газу від тиску (закон Генрі). В подальшому вплив тиску на розчинність газів буде вивчатися в курсі фізичної та колоїдної хімії і біохімії. Оскільки на різниці парціальних тисків кисню та вуглекислого газу в крові і в повітрі грунтується газообмін у легенях $[7,8]$.

Окрім того, зміну розчинності газів у крові слід враховувати при потраплянні людини в екстремальні умови, пов'язані зі зміною атмосферного тиску. Підйом високо в гори (зниження атмосферного тиску) призводить до погіршення постачання тканин киснем, різко зростає легенева вентиляція, що супроводжується зниженням вмісту $\mathrm{CO}_{2}$ та розвитком алкалозу. Частково це явище можна усунути вживанням цитратної (лимонної) кислоти. I навпаки, часте занурення у воду водолазів може стати причиною розвитку кесонної хвороби, оскільки при опусканні на глибину, внаслідок збільшення тиску, концентрація газів (кисню та азоту) у крові зростає. Швидке піднімання водолазів призводить до зменшення тиску, а отже, до бурхливого виділення розчинних у крові газів. Це стає причиною закупорювання капілярних кровоносних судин (газова емболія), порушення кровопостачання органів, що може спричинити серйозні функціональні розлади. Про явище емболії необхідно пам'ятати й при внутрішньовенному введенні лікарських засобів. 
Тема заняття: “Способи вираження складу розчинів"

Кількісне визначення діючих речовин у лікарських засобах достатньо часто проводять титриметричним методом (курси аналітичної та фармацевтичної хіміiі), в якому як титрант використовують розчини 3 точно відомою концентрацією. Отже, студенти повинні в курсі загальної хімії навчитися розраховувати різні види концентрацій, вміти робити перерахунки з однієї концентрації в іншу, та розраховувати масу наважки (об'єм розчину) для приготування розчину певного об'єму та з точно відомою концентрацією.

Тема заняття: "Колігативні властивості розчинів"

Освоєння колігативних властивостей розчинів необхідне в подальших курсах аналітичної та фармацевтичної хімії - для аналізу лікарських препаратів, що має економічне та юридичне значення.

Отже, в цілому можна вважати, що властивості розчинів й явища, які в них відбуваються, пояснюють теорії електролітичної дисоціації сильних і слабких електролітів, закони Рауля, Вант-Гоффа. На їх основі студенти прогнозують і пояснюють явища, а на основі знання законів та їх математичних формул роблять розрахунки та відображають їх наслідки. Емпіричні закономірності перебігу фізико-хімічних, біологічних процесів у розчинах з однієї сторони заповнюють і підтверджують закони, з іншого боку несуть важливу системоутворювальну функцію, забезпечують контакт даного блоку знань із іншими, а також є основою взаємозв'язку законів з експериментом і практикою. На цій основі студенти можуть прогнозувати й моделювати конкретні явища й процеси, у тому числі біохімічні.

На цьому занятті студенти вперше знайомляться з поняттям “ізотонічні, гіпотонічні та гіпертонічні розчини", явищем осмосу та тургору клітин. Ця тема тісно пов' язана з фізіологією людини та поглиблюється її вивчення в курсі патологічної фізіології, біохімії, фізичної та колоїдної хімії, фармакології, аптечної технології ліків.

Оскільки використання гіпотонічних розчинів (водних розчинів Л3) призводить до гемолізу еритроцитів, а гіпертонічних - до плазмолізу, то основною вимогою до використання інфузійних розчинів, очних крапель $є$ використання ізотонічних розчинів (0,9\% розчин натрій хлориду або 5 \% розчин глюкози). Осмотичний тиск цих розчинів дорівнює осмотичному тиску плазми крові. Однак часом є потреба у використанні гіпертонічних розчинів, наприклад, в хірургії для очистки гнійних ран (5-10\% розчин натрій хлориду), також розчини гіркої та глауберової солі використовують у медицині як послаблювальні розчини (можуть призначати при отруєнні алкалоїдами, щоб зменшити їх всмоктування в кишечнику та пришвидшити виведення).

Тема заняття: "Теорія кислот і основ. Дисоиіація води"

При викладанні даної теми викладач наголошує на те, що з основними поняттями “електроліти”, “сильні та слабкі електроліти”, “дисоціація води”, “рН розчину”, “буферний розчин” студенти будуть зустрічатися при вивченні аналітичної, біологічної, органічної, фармацевтичної, токсикологічної хімії [6-9].

Так, на заняттях з аналітичної хімії проводяться відповідні розрахунки рН не тільки концентрованих розчинів сильних кислот і основ, а й розбавлених, а також суміші сильних та слабких електролітів, буферних розчинів. Пояснюється використання буферних розчинів у кількісному аналізі. При проведенні комплексонометричного титрування ін'єкційних розчинів, що містять іони Магнію, Кальцію, а також цинквмісних мазей використовуються буферні розчини, для зв'язування іонів Гідрогену та можливості фіксування кінцевої точки титрування.

Буферні розчини використовуються і при проведенні судово-токсикологічного аналізу (якісного та кількісного) мінералізату біологічного матеріалу на наявність "металічних" отрут.

Три типи буферних розчинів (карбонатний, фосфатний, білковий) зберігають стале значення рН в організмі людини. Механізм їх дії вивчається в курсі біологічної хімії. $\mathrm{pH}$ крові людини в середньому становить 7,4, зміна цього значення навіть на одну десяту одиниці призводить до важких порушень (ацидозу або алкалозу). Коли водневий показник виходить за межі діапазону 6,8ч7,8, це зазвичай веде до загибелі. Ці патології вивчаються студентами на заняттях не тільки з біохімії, а й в курсі нормальної та патологічної фізіології.

3 поняттями “слабкі основи” та “кислоти” зустрічаються при вивченні курсу органічної, фармацевтичної та токсикологічної хімії. Оскільки більшість діючих речовин у лікарських засобах є органічного походження, студенти повинні розуміти, що залежно від будови молекули органічної речовини вона буде мати певні кислотно-основні властивості. Так, незважаючи на присутність у молекулі похідних барбітурової кислоти атомів Нітрогену, ці сполуки виявля- 
ють слабкі кислотні властивості і є малорозчинні у воді (тому у фарманалізі використовують неводне кислотно-основне титрування для їх кількісного визначення), і розчинні в розчинах лугів. При пероральному застосуванні барбітурати всмоктуються в шлунку, але маючи ліпофільні властивості, повільно метаболізують і накопичуються в головному мозку.

Тема заняття: "р-елементи VA групи. Азот. Сполуки Нітрогену у від'ємному ступені окиснення. Сполуки Нітрогену у додатному ступені окиснення"

Нітроген - один з шести найбільш важливих біогенних елементів організму. Його органічні (амінокислоти, пептиди, білки, вітаміни, гормони, а також лікарські засоби органічного та неорганічного походження) та неорганічні сполуки використовуються в аналізі та медицині.

Викладач звертає увагу студентів, що в медицині застосовуються різні нітрогенвмісні сполуки, зокрема, рідкий азот - для виведення папілом, судинних родимок зі шкіри, геміоксид нітрогену - для інгаляційного наркозу, 10 \% розчин аміаку - нашатирний спирт - для збудження дихання і виведення хворих 3 непритомності тощо.

Враховуючи леткість аміаку та його слабкі основні властивості для кількісного визначення як в аналітичній, так і у фармацевтичній хімії використовують зворотну протолітометрію.

Вже в курсі біохімії студенти-провізори вивчають токсичний вплив аміаку на організм людини і механізми його знешкодження (орнітиновий цикл КребсаХензелайта), в подальшому при вивченні токсикологічної хімії вони оволодівають методами ізолювання аміаку з трупного матеріалу та вдосконалюють методики якісного виявлення, які були отримані при вивченні курсу аналітичної та фармацевтичної хімії.

Як ми бачимо, практично кожна тема курсу неорганічної хімії є підгрунтям для вивчення інших дисциплін і знання, які отримують студенти, повинні закласти професійну орієнтацію для майбутнього провізора.

Ще однією базовою дисципліною, яка вивчається студентами фармацевтичних факультетів, є аналітична хімія. Вона базується на знаннях 3 неорганічної хіміі, фізики та математики та інтегрується з органічною, фармацевтичною, токсикологічною, фізколоїдною та біологічною хіміями; закладає основи вивчення фармацевтичної та токсикологічної хімій та передбачає формування умінь застосування одержаних знань для вивчення спеціальних дисциплін та у професійній діяльності.
Наведемо приклади реалізації міжпредметних зв'язків при вивченні деяких тем з аналітичної хімї̈.

Тема заняття: "Електрохімічні методи аналізу. Потенціометричне визначення рН розчинів, вмісту лікарських речовин”

Пряма потенціометрія, потенціометричне титрування, амперометричне титрування - фармакопейні методи аналізу. Теоретичні знання (основні закони, будова та використання електродів в різних методах аналізу) і практичні навички, які закладаються на даному занятті, в подальшому будуть поглиблені при вивченні курсу фізичної та колоїдної хімії, а також фармацевтичної хіміі.

Потенціометрія - один з важливих фізико-хімічних методів у фармацевтичному аналізі. Застосовується вона частіше як непрямий метод, тобто у формі титрування. Пряма потенціометрія є фармакопейним методом аналізу в плані контролю кислотності середовища. Жоден розчин (інфузійний чи ін'єкційний, сироп чи розчин іншого призначення) не може пройти стандартизацію без визначення $\mathrm{pH}$, за винятком рідких гідрофобних. Тому вивчення теоретичних основ потенціометрії займає важливе місце в аналітичній освіті майбутнього провізора. Методами потенціометричного титрування аналізують багато лікарських засобів, наприклад натрій хлорид, аскорбінову кислоту, сульфамідні препарати, барбітурати, алкалоїди.

Вольтамперометрія - фармакопейний метод аналізу, який раніше застосовувався для визначення саліцилової кислоти, норсульфазолу, вітаміну $\mathrm{B}_{1}$, алкалоїдів, фолієвої кислоти, келіну в порошку і в таблетках, нікотинаміду, піридоксину гідрохлориду, препаратів арсену, глікозидів серцевої дії, а також кисню і різних домішок у фармацевтичних препаратах.

Тема заняття: "Хроматографічні методи аналізу"

Хроматографічні методи аналізу (ТШХ, ГРХ, BEPX, паперова, іонообмінна хроматографіiі) застосовуються в якісному і кількісному аналізі лікарських засобів та для оцінки кількостей деяких домішок. Останнім часом, із підвищенням вимог до якості лікарських засобів, обов'язковими стали методи газової та високоефективної рідинної хроматографії в аналізі субстанцій і готових лікарських засобів. Іонообмінна хроматографія ще застосовується для кількісного визначення деяких субстанцій, проте із покращенням технічного оснащення контрольноаналітичних лабораторій вона відходить як метод контролю якості і залишається лише як метод розділення окремих іонних сполук. Тонкошарова хроматографія залишається важливим методом підтверджен- 
ня тотожності лікарських речовин, а попереднє їїзавдання - оцінка граничних вмістів домішок сторонніх речовин поступово передається газовій і високоефективній рідинній хроматографії.

Використання хроматографічних методів має місце не тільки при вивченні аналітичної та фармацевтичної хімії, а й при вивченні токсикологічної хіміі. Методом ТШХ проводять розділення отруйних речовин та їх метаболітів у витяжках з біологічного матеріалу. Також методи ГРХ, ВЕРХ, ТШХ використовуються для якісного і кількісного визначення отруйних та сильнодіючих речовин в біологічних рідинах, оскільки ці методи є одними 3 найбільш чутливих.

Таким чином, міжпредметна інтеграція в процесі навчання та державної атестації сприяє формуванню в студентів комплексних знань зі спеціальних дис-

\section{Література}

1. Беликов В. Г. Межпредметная интеграция преподавания специальных дисциплин в процессе обучения / В. Г. Беликов, И. Я. Куль // Сборник научных работ "Естествознание и гуманизм". - Томск, 2006. - Т. 3, вып. 3. - С. 85-86.

2. Компанцев В. А. Компетентностный подход к изучению неорганической химии как современная образовательная технология / В. А. Компанцев, Л. П. Гокжаева, Л. И. Щербакова // Пути и формы совершенствования фармацевтического образования : материалы 4-й Всероссийской с международным участием научно-методической конференции “Фармобразование 2010”, - Воронеж, 2010. -C. 61-63.

3. Межпредметная интеграция курса общей химии в медицинском вузе / Т. Н. Литвинова, Н. К. Выскубова, С. А. Овчинникова [и соавт.] // Фундаментальные исследования. -2004 . - № 3. - С. 73-75.

4. Литвинова Т. Н. Межпредметная интеграция химических дисциплин в медицинском вузе / Т. Н. Литвинова, И. М. Быков, Н. К. Волкова // Современные проблемы науки и образования. - 2009. - № 2. - С. 51-52. циплін і підготовці всебічно кваліфікованого випускника фармацевтичного вузу.

Висновки: 1. Міжпредметна інтеграція дозволяє проводити поетапну організацію роботи із впровадження міжпредметних зв'язків, постійно ускладнюючи пізнавальні задачі, розширюючи поле дії творчої ініціативи та пізнавальної самостійної діяльності студента, застосовуючи все різноманіття дидактичних засобів для ефективного здійснення багатосторонніх міжпредметних зв'язків.

2. Використання міжпредметних зв'язків у реалізації принципів наступності та неперервності відіграє позитивну роль як для закріплення певних тем i розділів, так і для засвоєння найважливіших узагальнюючих понять, що зустрічаються в різних курсах хімії й спеціальних дисциплін.

5. Семенов В. Н. Химия общая и неорганическая в системе фармацевтического образования / В. И. Семенов, Л. Я. Твердохлебова // Пути и формы совершенствования фармацевтического образования : материалы 4-й Всероссийской с международным участием научно-методической конференции “Фармобразование 2010”. - Воронеж, 2010. - С. 122-123.

6. Левітін Є. Я. Загальна та неорганічна хімія/Э. Я. Левітін. - Х. : Прапор, НФАУ, 2000. - 464 с.

7. Гонський Я. І. Біохімія людини : підручник / Я. І. Гонський, Т. П. Максимчук. - Тернопіль : Укрмедкнига, 2001. $-736 \mathrm{c}$.

8. Біофізична та колоїдна хімія : посіб. для студ. фармац. фак. і фармац. ВНЗ III-IV рівнів акредитації, за спец. "Клінічна фармація" і “Фармація" / [А. С. Мороз, Л. П. Яворська, Д. Д. Луцевич та ін.]; за заг. ред. А. С. Мороза. - Вінниця : Нова Книга, 2007. -600 с.

9. Болотов В. В. Аналітична хімія : навчальний посібник / В. В. Болотов. - Х. : Прапор, НфаУ, 2004. -480 с. 